\title{
Oxygen limitation of thermal tolerance defined by cardiac and ventilatory performance in spider crab, Maja squinado
}

\author{
MARKUS FREDERICH AND HANS O. PÖRTNER \\ Alfred Wegener Institute for Polar and Marine Research, 27568 Bremerhaven, Germany \\ Received 6 December 1999; accepted in final form 25 May 2000
}

\begin{abstract}
Frederich, Markus, and Hans O. Pörtner. Oxygen limitation of thermal tolerance defined by cardiac and ventilatory performance in spider crab, Maja squinado. Am J Physiol Regulatory Integrative Comp Physiol 279: R1531-R1538, 2000.-Geographic distribution limits of ectothermal animals appear to be correlated with thermal tolerance thresholds previously identified from the onset of anaerobic metabolism. Transition to these critical temperatures was investigated in the spider crab (Maja squinado) with the goal of identifying the physiological processes limiting thermal tolerance. Heart and ventilation rates as well as $\mathrm{PO}_{2}$ in the hemolymph were recorded on-line during progressive temperature change between 12 and $0^{\circ} \mathrm{C}\left(1^{\circ} \mathrm{C} / \mathrm{h}\right)$ and between 12 and $40^{\circ} \mathrm{C}\left(2^{\circ} \mathrm{C} / \mathrm{h}\right)$. Lactate and succinate were measured in tissues and hemolymph after intermediate or final temperatures were reached. High levels of hemolymph oxygenation suggest that an optimum range of aerobic performance exists between 8 and $17^{\circ} \mathrm{C}$. Thermal limitation may already set in at the transition from optimum to pejus (pejus = turning worse, progressively deleterious) range, characterized by the onset of a decrease in arterial $\mathrm{PO}_{2}$ due to reduced ventilatory and cardiac performance. Hemolymph $\mathrm{PO}_{2}$ values fell progressively toward both low and high temperature extremes until critical temperatures were reached at $\sim 1$ and $30^{\circ} \mathrm{C}$, as indicated by low $\mathrm{PO}_{2}$ and the onset of anaerobic energy production by mitochondria. In conclusion, the limited capacity of ventilation and circulation at extreme temperatures causes insufficient $\mathrm{O}_{2}$ supply, thereby limiting aerobic scope and, finally, thermal tolerance.
\end{abstract}

aerobic capacity; anaerobic metabolism; optodes; partial pressure of oxygen

CRITICAL TEMPERATURES $\left(\mathrm{T}_{\mathrm{c}}\right)$ have been defined for different marine invertebrate and fish species as being characterized by the onset of anaerobic metabolism, which is caused by a mismatch of $\mathrm{O}_{2}$ demand and $\mathrm{O}_{2}$ supply (for review, see Refs. 35 and 36). Extended exposure to temperatures above high $\mathrm{T}_{c}$ or below low $\mathrm{T}_{\mathrm{c}}$ finally leads to death of the animal unless thermal acclimation, i.e., a shift of $\mathrm{T}_{\mathrm{c}}$ values, occurs $(40,51)$. One hypothesis is that the adjustment of mitochondrial density and capacity is involved in setting thermal tolerance limits and is therefore related to geographic distribution $(35,36)$. As a consequence, the relationship between $\mathrm{O}_{2}$ availability to tissues and $\mathrm{O}_{2}$ demand appears to be crucial for survival of exposure to tem-

\footnotetext{
Address for reprint requests and other correspondence: $\mathrm{H}$. O. Pörtner, Alfred-Wegener-Institute for Polar and Marine Research, Columbusstrasse, 27568 Bremerhaven, Germany (E-mail: hpoertner @AWI-Bremerhaven.de).
}

perature extremes. Study of the processes of $\mathrm{O}_{2}$ uptake by ventilation and $\mathrm{O}_{2}$ distribution by circulation therefore appear important to further our understanding of the $\mathrm{O}_{2}$ limitation of thermal tolerance. Therefore, we chose to study these systemic aspects of thermal tolerance, selecting a crustacean, Maja squinado (Herbst), as a model organism. As yet, physiological studies of crustaceans have addressed temperature effects on $\mathrm{O}_{2}$ consumption, heart and ventilatory performance, or growth $(12-14,16,23,34,44)$. In most of these studies, temperatures were chosen within the physiological range. Hence, there is little information on parameters that become limiting on both sides of the window of thermal tolerance in this group.

The present study was designed to investigate the effect of acute temperature change on $\mathrm{Po}_{2}$ in the hemolymph of Maja squinado combined with an analysis of ventilation and heart rates as the processes responsible for $\mathrm{O}_{2}$ uptake and distribution. Maja squinado was chosen under the assumption that the identification of a low $\mathrm{T}_{\mathrm{c}}$ would be easier in this warm-adapted species than in cold-adapted species. Maja squinado is found between the warm waters of the north African coast and the west and south coasts of England and only occasionally occurs in the German Bight $(9,22)$.

\section{MATERIALS AND METHODS}

Animals. Adult male and female Maja squinado were obtained from local fishermen in Roscoff, France, in November 1998. Animals were kept in large tanks with aerated natural seawater at $10^{\circ} \mathrm{C}$, and most of them were transported within $15 \mathrm{~h}$ from Roscoff to the Alfred Wegener Institute in Bremerhaven, Germany. They were held in tanks with aerated, recirculating natural seawater at $10 \pm 0.5^{\circ} \mathrm{C}$ and $32 \%$ salinity. The animals were fed twice a week with pieces of cod (Gadus morhua) and mussels (Mytilus edulis). Experiments were carried out at the Station Biologique de Roscoff and at the Alfred Wegener Institute.

Surgical procedure and on-line data recording. Animals were prepared for experimentation by drilling a small hole through the carapace directly behind the heart, avoiding injury to the hypodermis. The hole was covered with a latex dam to prevent hemolymph loss during the following surgery. A glass capillary was inserted through the latex dam $1 \mathrm{~mm}$ deep into the carapace and fixed with dental periphery wax.

\footnotetext{
The costs of publication of this article were defrayed in part by the payment of page charges. The article must therefore be hereby marked "advertisement" in accordance with 18 U.S.C. Section 1734 solely to indicate this fact.
} 
To identify the optimum position of the $\mathrm{O}_{2}$ sensor in the pericardial sinus, a cannula was fed through the capillary into the pericardial sinus until pulsation of the hemolymph level could be seen in the capillary. The cannula was removed, and a calibrated optode (a fiber-optic oxygen sensor; see description below and Refs. 25 and 26) was inserted through the glass capillary, brought to exactly the same position, and fixed with dental periphery wax.

Animals were kept in a temperature-controlled 25-liter aquarium with air-saturated seawater. $\mathrm{PO}_{2}$ of the seawater changed slightly with temperature between $157.9 \pm 1.1$ $\mathrm{mmHg}$ at $0^{\circ} \mathrm{C}$ and $147.0 \pm 1.2 \mathrm{mmHg}$ at $40^{\circ} \mathrm{C}$, depending on the temperature dependence of water vapor pressure. Arterial $\mathrm{Po}_{2}$ in postbranchial hemolymph was monitored on-line in the pericardial sinus by implanted optodes. Two different instruments, Microx I (PreSens, Neuburg/Donau, Germany) and Mops-4 (Comte, Hannover, Germany) were used. Both companies provide sensors with an oxygen-sensitive fluorophor [tris (2,2'-bipyride)-ruthenium(II)-chloride immobilized in silicone for Mops-4] fixed on the tip of an optic fiber. Sensor diameter is $50 \mu \mathrm{m}$ in Microx I and $600 \mu \mathrm{m}$ in Mops-4. Microx I quantifies the phase angle shift of emitted light based on oxygen-dependent dynamic quenching of luminescence (25, 26), whereas Mops-4 quantifies the intensity shift of the signal caused by different levels of $\mathrm{Po}_{2}$. Despite the differences in tip size and in the principle of measurement, the systems showed the same results with respect to time resolution and accuracy. For most of the measurements, Mops-4 was used because the tips are less fragile and easier to handle because of their larger diameter. Temperature shift of the signal was calculated by linear calibration curves recorded with each optode between 0 and $40^{\circ} \mathrm{C}$. By calculating temperature-compensated calibration values at intervals of $0.1^{\circ} \mathrm{C}$, it was possible to correct $\mathrm{O}_{2}$ recordings for temperature, which was monitored with a PT100 thermometer (isiTEC, Bremerhaven, Germany).

Heart and ventilation activity were monitored by the noninvasive technique introduced by Depledge (11) and described in more detail elsewhere (18). Photoplethysmographs (isiTEC) were glued onto the carapace above the heart and on both sides below the scaphognathite. Data were recorded by a MacLab system (AD Instruments) at a rate of $0.1 \mathrm{~Hz}$ for $\mathrm{Po}_{2}$ and $20 \mathrm{~Hz}$ for heart and ventilation rates.

Animals moved freely during the experiments; only the chelae were covered with two small pieces of tubing to prevent the crabs from destroying the ventilation sensors. They had a minimum of $12 \mathrm{~h}$ to recover at $12 \pm 0.2^{\circ} \mathrm{C}$ before being cooled to $0^{\circ} \mathrm{C}$ within $12 \mathrm{~h}\left(1^{\circ} \mathrm{C} / \mathrm{h}\right)$ or warmed to $40^{\circ} \mathrm{C}$ within $14 \mathrm{~h}\left(2^{\circ} \mathrm{C} / \mathrm{h}\right)$. Time courses were set by the capacity of the thermostat (Lauda RC6CP, Lauda-Königshofen, Germany) used for temperature control. At the end of the experiments, optodes were removed and calibration was checked for drift due to damage caused by the penetrated tissue. Implanted optodes could be used for $48 \mathrm{~h}$ without drift by $>2 \%$. During longer implantations, an aggregation of proteins or other material appeared on the tip of the optode and response time was extended. All animals survived the surgical procedure.

Lactate and succinate measurements. Samples for the analysis of anaerobic end products were collected during an experiment carried out with freshly caught animals in Roscoff. Crabs ( 6 for each temperature) were maintained in 80 -liter aquaria. After a 12 -h period at $12.5^{\circ} \mathrm{C}$, temperature was increased or decreased to $-0.3,7.9,21.6$, and $33.3^{\circ} \mathrm{C}$ at a rate comparable to that used during measurements of $\mathrm{PO}_{2}$ and heart rate. After the final temperatures were reached, hemolymph samples were withdrawn via a cannula inserted through the articular membrane of the coxa of the last walking leg. Animals were dissected by cutting off the rostrum, including the cerebral ganglion, and opening the carapace. Tissue samples were excised from heart, hepatopancreas, and musculature of meropodites of different walking legs. The dissection was finished within $60 \mathrm{~s}$. Samples were freeze clamped immediately (48) and stored in liquid nitrogen until analysis.

For metabolite analyses (3), samples were pulverized under liquid nitrogen using mortar and pestle. Protein was precipitated with $0.6 \mathrm{~mol} / \mathrm{l}$ perchloric acid by homogenization of the sample with an Ultraturrax (IKA, Staufen, Germany) at maximum speed and simultaneous cooling on ice. Precipitates were removed by centrifugation at $14,000 \mathrm{rpm}$. Supernatants were neutralized with $5 \mathrm{~mol} / \mathrm{K} \mathrm{KOH}$, followed by centrifugation for the removal of precipitated $\mathrm{KClO}_{4}$. L-Lactate and succinate were measured enzymatically using photometric standard tests (3).

Statistics. $\mathrm{PO}_{2}$ and heart and ventilation rate data were analyzed for break points identifying a change in the relationship to temperature using a Q-BASIC program that determines intersections of fitted regressions at the minimized sum of residual sums of squares (49). Significance of differences between fitted regressions was tested using analysis of covariance (ANCOVA, SuperAnova, Abacus Concepts) and Student-Newman-Keuls test at the $P<0.05$ level. Metabolite data were tested for significance of differences at the $P<0.05$ level using ANOVA (SuperAnova). Data are given as means $\pm \mathrm{SD}$.

\section{RESULTS}

Animals exhibited great variability in hemolymph $\mathrm{PO}_{2}$ and heart and ventilation rates at control temperature and during temperature decrease or increase. No differences could be found between male and female specimens (mean wt $595 \pm 151 \mathrm{~g}$ ). After $12 \mathrm{~h}$ at $12 \pm$ $0.2^{\circ} \mathrm{C}$, mean $\mathrm{Po}_{2}$ was $92.6 \pm 27.8 \mathrm{mmHg}(n=13$; for minimum and maximum values, see Table 1.). Mean heart rate was $52.9 \pm 14.8$ beats/min, and ventilation rate differed between left and right scaphognathites, as reported previously for different crustacean species $(6,31-33)$. Mean ventilation rate of both scaphognathites in 13 different animals was $60.0 \pm 28.3$ beats/ min at $12^{\circ} \mathrm{C}$. As an example, Fig. 1 shows the typical variability in $\mathrm{Po}_{2}$ and heart and ventilation rates for one specimen at $12^{\circ} \mathrm{C}$ over a period of $13 \mathrm{~h}$. This animal exhibited large fluctuations in $\mathrm{PO}_{2}$ with a low mean of $27.2 \pm 12.5 \mathrm{mmHg}$ and no period of constant $\mathrm{Po}_{2}$ throughout. $\mathrm{Po}_{2}$ varied between 3.1 and $55.7 \mathrm{mmHg}$. Although this animal exhibited a low mean $\mathrm{Po}_{2}$ value compared with others, the pattern of $\mathrm{PO}_{2}$ fluctuations

Table 1. $\mathrm{PO}_{2}$, heart rate, and ventilation rate after $12 \mathrm{~h}$ of incubation at $12.1 \pm 0.2^{\circ} \mathrm{C}$ in Maja squinado

\begin{tabular}{lccc}
\hline \hline & $\mathrm{Po}_{2}, \mathrm{mmHg}$ & $\begin{array}{c}\text { Heart Rate, } \\
\text { beats/min }\end{array}$ & $\begin{array}{c}\text { Ventilation Rate, } \\
\text { beats/min }\end{array}$ \\
\hline Mean $\pm \mathrm{SD}$ & $92.0 \pm 27.8$ & $52.9 \pm 14.8$ & $60.0 \pm 28.3$ \\
Maximum & 134.8 & 138.4 & 99.4 \\
Minimum & 33.3 & 5.0 & 0.0
\end{tabular}

$n=13$ animals. Ventilation rate values are means of both scaphognathites. Large interindividual differences coincided with extreme fluctuations in all investigated parameters, including severe bradycardia and apnea. 


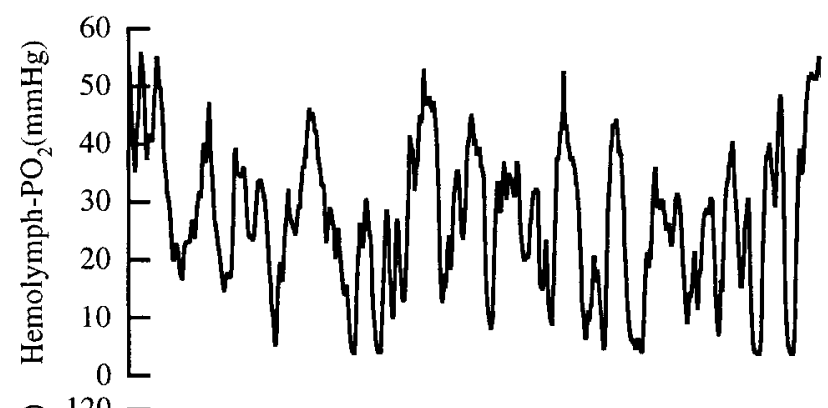

that no acute over- or undershoot reaction was involved. It also demonstrates that the rate of cooling or heating was sufficient to bring $\mathrm{Po}_{2}$ close to steady state for each temperature analyzed.

The drop in $\mathrm{PO}_{2}$ with rising or falling temperature was curvilinear toward both ends of the temperature window, with a range of maximum $\mathrm{Po}_{2}$ between 8 and $17^{\circ} \mathrm{C}(92.6 \pm 6.4 \mathrm{mmHg}) . \mathrm{Po}_{2}$ decreases at low and high temperatures were not symmetrical; a tailing was visible toward higher temperatures (Fig. 2). Ventilation rate increased linearly between 6 and $17^{\circ} \mathrm{C}$ at an average rate of $8.2 \pm 2.6$ beats $\cdot \min ^{-1} \cdot{ }^{\circ} \mathrm{C}^{-1}$. Below $8^{\circ} \mathrm{C}$, the ventilation rate dropped sharply $(P<0.05$, ANCOVA) and rose again to $18.8 \pm 10.9$ beats $/ \mathrm{min}$ at $3.7^{\circ} \mathrm{C}$ without a visible effect on $\mathrm{Po}_{2}$. During warming above $17^{\circ} \mathrm{C}$, no further increase in ventilation rate occurred but ventilation leveled off significantly $(P<$ 0.05 , ANCOVA) and even decreased slightly, $-2.1 \pm$ 0.2 beats $\cdot \min ^{-1} \cdot{ }^{\circ} \mathrm{C}^{-1}$. Beyond $30^{\circ} \mathrm{C}$, a significant $(P<$ 0.05 , ANCOVA) steep reduction $(-10.6 \pm 0.3$ beats $\cdot \min ^{-1} \cdot{ }^{\circ} \mathrm{C}^{-1}$ ) occurred after a transitional rise at $30^{\circ} \mathrm{C}$. Apnea occurred at $39.7^{\circ} \mathrm{C}$.

Heart rate also showed this triphasic behavior between 6 and $40^{\circ} \mathrm{C}$, with a slight but nonsignificant $(P>$ 0.05 , ANCOVA) reduction in slope from $3.3 \pm 0.1$ to $1.8 \pm 0.2$ beats $\cdot \min ^{-1} \cdot{ }^{\circ} \mathrm{C}^{-1}$ at $14.4^{\circ} \mathrm{C}$. A sudden, temporary increase at $30^{\circ} \mathrm{C}$ was followed by a significant $(P<0.05$, ANCOVA $)$ decrease $(-9.3 \pm 0.3$ beats. $\min ^{-1} .{ }^{\circ} \mathrm{C}^{-1}$ ) until acardia was reached at $40.5^{\circ} \mathrm{C}$, which led to death when temperature was not reduced to control values immediately. At low temperatures, a depression in heart rate below $8^{\circ} \mathrm{C}$ coincided with the observed sharp decrease in ventilation rate and a slight reduction in $\mathrm{PO}_{2}$. Below $4^{\circ} \mathrm{C}$, heart rate decreased again, followed by an increase to $12.9 \pm 4.9$ beats/min. This small increase in heart rate around $1^{\circ} \mathrm{C}$ represents a final "tachycardia" before acardia sets in, with no cardiac output being detectable, as shown by Frederich et al. (17) using the Doppler technique. Animals survived when temperature was increased above $0^{\circ} \mathrm{C}$ again within $30 \mathrm{~min}$.

Heart rate proved to be more resistant to tempera-

Fig. 1. Recording of hemolymph $\mathrm{PO}_{2}$, ventilation rate, and heart beat rate at $12^{\circ} \mathrm{C}$ for 1 specimen of Maja squinado over a period of $13 \mathrm{~h}$. Fluctuations in $\mathrm{PO}_{2}$ correspond to those in ventilation rate more than to those in heart rate. Apnea is often related to bradycardia and sometimes followed by a short burst of tachycardia.

was similar in all investigated specimens. Periods of apnea corresponded to very low hemolymph $\mathrm{O}_{2}$ levels. Bradycardia occurred together with apnea and large drops in $\mathrm{PO}_{2}$, whereas smaller fluctuations in $\mathrm{Po}_{2}$ and ventilation rate were not correlated with bradycardia events. Short bursts of tachycardia seemed to compensate for periods of bradycardia.

When temperature decreased or increased, major changes occurred in cardiac and ventilatory performance and $\mathrm{PO}_{2}$. Initial trials confirmed that after temperature changed from 12 to 5 or $20^{\circ} \mathrm{C}, \mathrm{Po}_{2}$ changed initially but remained at a constant mean level for $6 \mathrm{~h}$ after the new temperature was reached. This implies ture change than ventilation rate and $\mathrm{Po}_{2}$. Therefore, ventilatory performance seemed to be more crucial for surviving extreme temperatures. As a consequence, $\mathrm{T}_{\mathrm{c}}$ and preference and tolerance ranges were identified especially from ventilation rate and $\mathrm{PO}_{2}$ data. Calculated intersections of fitted regressions (Table 2) confirmed visible break points at 8 and $17^{\circ} \mathrm{C}$. Because temperatures of 8 and $17^{\circ} \mathrm{C}$ indicate the transition from optimum to an increasingly deleterious range (called the pejus range; see DISCUSSION), they are called pejus temperatures $\left(\mathrm{T}_{\mathrm{p} I}\right.$ and $\left.\mathrm{T}_{\mathrm{p} \text { II }}\right)$. The lower pejus temperature $\left(\mathrm{T}_{\mathrm{p}}\right)$ was characterized by a sudden decrease in ventilation and heart rates accompanied by a slight reduction in $\mathrm{Po}_{2}$ at $8^{\circ} \mathrm{C}$. Apnea set in at minimum $\mathrm{Po}_{2}$, and the temperature at this point was defined as the low $\mathrm{T}_{c}\left(\mathrm{~T}_{c \mathrm{I}} ; 1^{\circ} \mathrm{C}\right)$ because anaerobic metabolism was observed slightly below this value (see Fig. 4). Similarly, the upper break point at $30^{\circ} \mathrm{C}$ was identified as the upper $\mathrm{T}_{\mathrm{c}}\left(\mathrm{T}_{\mathrm{c} \text { II }}\right)$ because significant anaer- 
Fig. 2. $\mathrm{Po}_{2}$, ventilation, and heart rate for Maja squinado between 0 and $40^{\circ} \mathrm{C}$. Threshold temperatures $\left(\mathrm{T}_{\mathrm{cI}}\right.$, $\mathrm{T}_{\mathrm{pI}}, \mathrm{T}_{\mathrm{pII}}$, and $\mathrm{T}_{\mathrm{cII}}$ ) are identified by break points in ventilation rate and corresponding changes in $\mathrm{PO}_{2}$ and heart rate. $\mathrm{T}_{\mathrm{cI}}$ and $\mathrm{T}_{\mathrm{cII}}$ correspond to critical tempera4) and death, whereas $\mathrm{T}_{\mathrm{pI}}$ and $\mathrm{T}_{\mathrm{pII}}$ indicate threshold values at the transition from optimum to pejus range. Values are means $\pm \mathrm{SD} ; n=13$. tures characterized by the onset of anaerobiosis (cf. Fig.
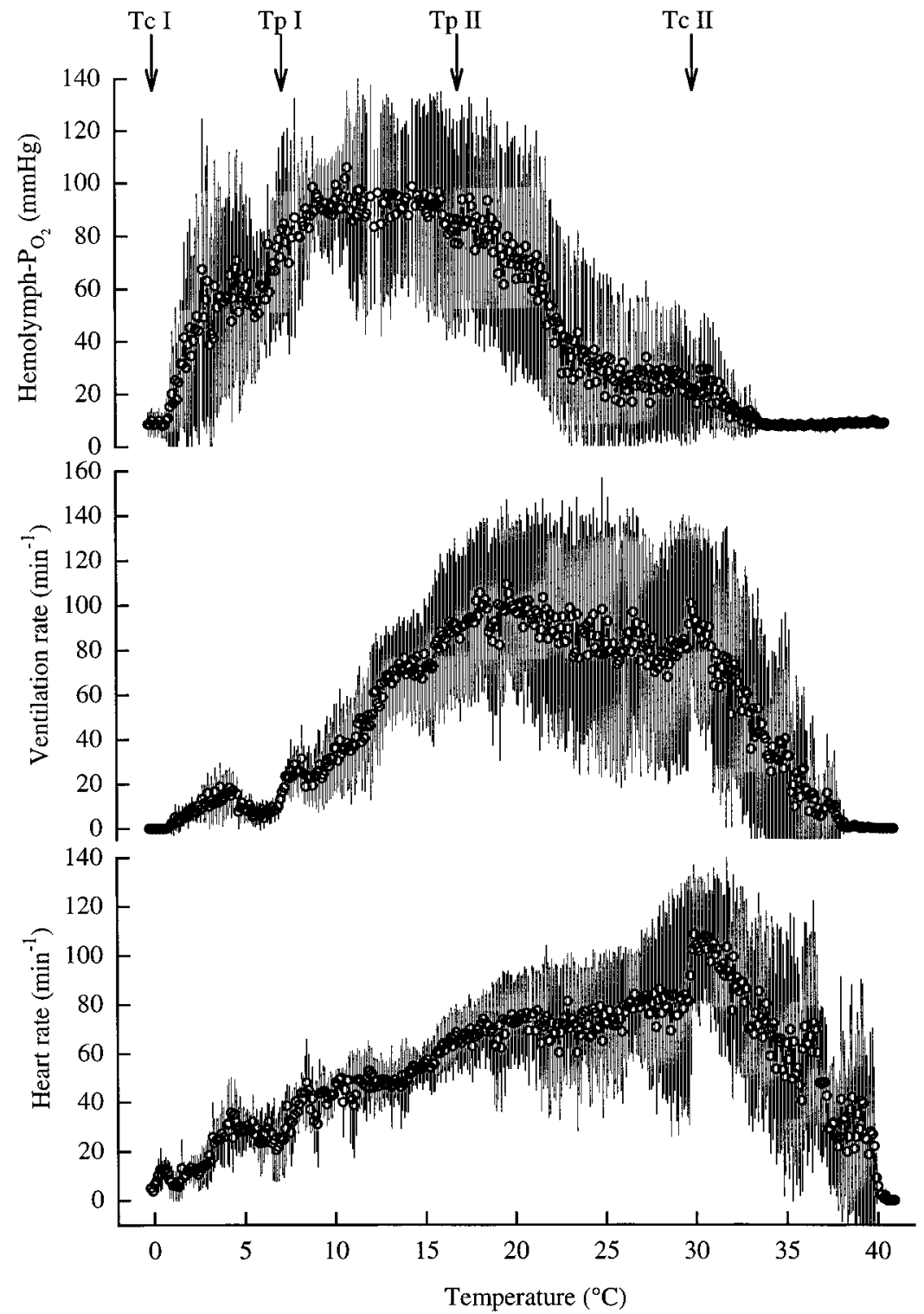

obic energy production occurred slightly above this value (see Fig. 4 and DISCUSSION).

Arterial $\mathrm{PO}_{2}$ is clearly dependent on ventilation rate because ventilation sets the amount of $\mathrm{O}_{2}$ available to the animal. Figure 3 shows two different patterns of

Table 2. Threshold temperatures in Maja squinado for changes in $\mathrm{PO}_{2}$, heart rate, and ventilation rate

\begin{tabular}{lcccc}
\hline \hline & $\mathrm{T}_{\mathrm{cI}}$ & $\mathrm{T}_{\mathrm{pI}}$ & $\mathrm{T}_{\mathrm{pII}}$ & $\mathrm{T}_{\mathrm{cII}}$ \\
\hline $\mathrm{Po}_{2}$ & 0.7 & 8.9 & 17.8 & 30.9 \\
Ventilation rate & 0.7 & 9.3 & 17.3 & 31.1 \\
Heart rate & -0.1 & n.v. & n.v. & 31.5 \\
\hline
\end{tabular}

Values (in ${ }^{\circ} \mathrm{C}$ ) were identified by intersections of best fitted regressions for each parameter. $T_{c}$, critical temperature; $T_{p}$, pejus temperature; $\mathrm{T}_{c I}$ and $\mathrm{T}_{c I I}$, lower and upper $\mathrm{T}_{c}$ characterized by onset of anaerobic metabolism; $\mathrm{T}_{\mathrm{pI}}$ and $\mathrm{T}_{\mathrm{pII}}$, lower and upper $\mathrm{T}_{\mathrm{p}}$ characterized by transition from optimum to pejus range; n.v., not visible. The pattern of changes in heart rate did not reveal $\mathrm{T}_{\mathrm{pI}}$ and $\mathrm{T}_{\mathrm{pII}}$ as significant discontinuities. correlation depending on the temperature range. Below $17^{\circ} \mathrm{C}$, which was determined as the upper $\mathrm{T}_{\mathrm{p}}\left(\mathrm{T}_{\mathrm{p} \text { II }}\right)$ for ventilation, $\mathrm{PO}_{2}$ increased strongly with ventilation rate. Maximum oxygenation was reached at $\sim 40$ beats/ min. Further acceleration of scaphognathite beat frequency did not result in elevated hemolymph $\mathrm{PO}_{2}$. This situation changed in the temperature range above $17^{\circ} \mathrm{C}$. High levels of $\mathrm{Po}_{2}$ were reached only at ventilation rates of 80-100 beats/min. A lower scaphognathite beat frequency was not sufficient to maintain high $\mathrm{O}_{2}$ levels in the hemolymph.

Lactate was found to accumulate significantly in hemolymph, musculature, hepatopancreas, and heart tissue at $33.3^{\circ} \mathrm{C}$ (Fig. 4). Lactate levels rose significantly in the musculature already at $21.6^{\circ} \mathrm{C}$ but only to a small, nonsignificant extent during cooling. A minor increase in the hepatopancreas and in the hemolymph at $-0.3^{\circ} \mathrm{C}$ was also nonsignificant. Succinate accumulated significantly in all investigated tissues at $33.3^{\circ} \mathrm{C}$ 


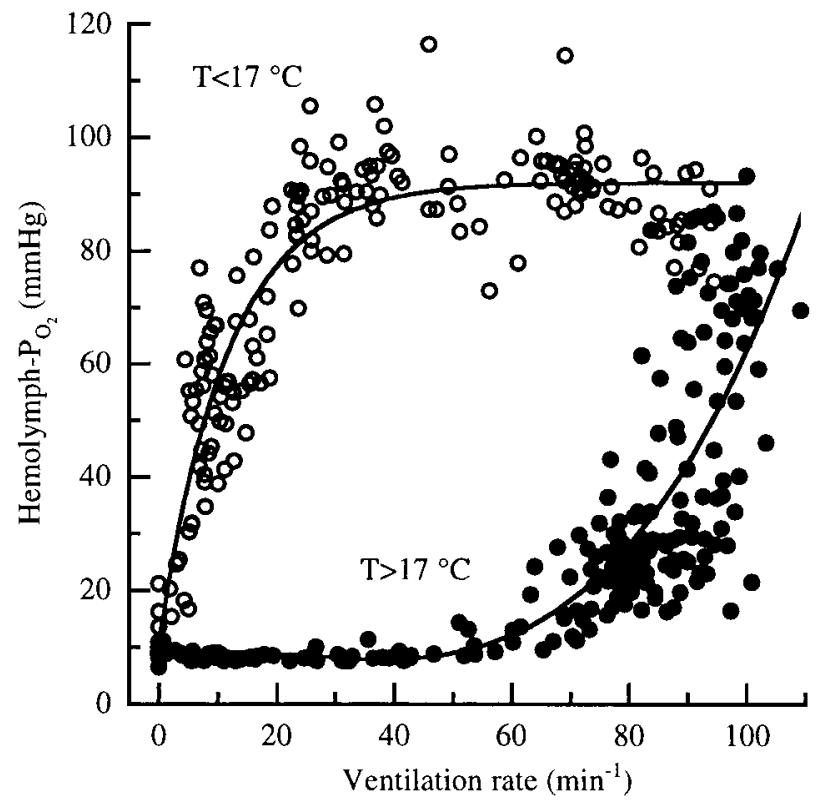

Fig. 3. Correlated changes in ventilation rate and hemolymph $\mathrm{Po}_{2}$ for the temperature range $0-17^{\circ} \mathrm{C}(\circ)$ and $17-40^{\circ} \mathrm{C}(\bullet)$.

and in the hepatopancreas only at $-0.3^{\circ} \mathrm{C}$. As with lactate, the trend for succinate levels to rise remained nonsignificant in the other tissues at $-0.3^{\circ} \mathrm{C}$.

\section{DISCUSSION}

The on-line recordings of arterial $\mathrm{PO}_{2}$ by fiber-optic oxygen sensors proved to be a suitable and reliable method for the quantification of dynamic temperature effects on hemolymph $\mathrm{O}_{2}$ levels in Maja squinado. This technique allows investigation of changes in $\mathrm{Po}_{2}$ with temperature over time and avoids disturbance by repeated sampling, as required by other experimental protocols (see, for example, Refs. 15, 30, 45). It also avoids immobilization of the animal, as required for the use of fragile microelectrodes (2). $\mathrm{PO}_{2}$ was investigated because it reflects both the efficiency of arterial $\mathrm{O}_{2}$ uptake and the pressure head for $\mathrm{O}_{2}$ diffusion from the hemolymph to tissue mitochondria.

Hemolymph $\mathrm{PO}_{2}$ is buffered by hemocyanin-bound $\mathrm{O}_{2}$. We refrained from studying temperature effects on $\mathrm{O}_{2}$ binding by hemocyanin, although different studies have shown that parameters such as half-saturation pressure $\left(\mathrm{P}_{50}\right)$ and Bohr shift change with temperature in crustaceans (for review, see Refs. 7, 8, 27-29). Hemocyanin characteristics suggest that $\mathrm{O}_{2}$ binding at the gills may become insufficient at high temperature and $\mathrm{O}_{2}$ unloading in the tissues may be incomplete at low temperature (29). In our study, release of $\mathrm{O}_{2}$ from hemocyanin is likely to explain the tailing in the $\mathrm{Po}_{2}$ decrease between 23 and $32^{\circ} \mathrm{C}$ visible at a hemolymph $\mathrm{Po}_{2}$ of $24.5 \pm 6.5 \mathrm{mmHg}$ (Fig. 2). As expected, $\mathrm{Po}_{2}$ buffering occurred close to the $\mathrm{P}_{50}$ of Maja squinado hemocyanin, which amounts to $21.0 \mathrm{mmHg}$ at $15^{\circ} \mathrm{C}$ and is expected to rise with temperature (28). In any case, hemocyanin oxygenation is a secondary parameter to quantify $\mathrm{O}_{2}$ availability to tissues, whereas ar- terial hemolymph $\mathrm{PO}_{2}$ is a direct indicator because it correlates with the level of physically dissolved $\mathrm{O}_{2}$ and represents the pressure head driving diffusion.

Fluctuations in $\mathrm{Po}_{2}$ and corresponding heart and ventilation rates under resting conditions were similar to those described for the crayfish Astacus leptodactylus (2). Mean $\mathrm{Po}_{2}$ values of $92.6 \pm 6.4 \mathrm{mmHg}$ between 8 and $17^{\circ} \mathrm{C}$ are in the upper range of $\mathrm{Po}_{2}$ data compiled by McMahon and Wilkens (33) and Mangum (28) for 28 decapod species and much higher than reported for Carcinus maenas and Necora puber (30). Forgue et al. (15) reported a mean $\mathrm{PO}_{2}$ of $45.8 \mathrm{mmHg}$ at $15^{\circ} \mathrm{C}$ for Maja squinado. This value is still within the range of interindividual variability in $\mathrm{Po}_{2}$ seen in the present study.

To investigate the response to fluctuating temperature, we changed temperature quite rapidly over a wide range. The fast, progressive temperature change minimized acclimation phenomena that may involve shifts in thermal thresholds (e.g., associated with changes in mitochondrial density; Ref. 36). Reactions to such a progressive temperature change will take longer at low than at high temperatures because of the $\mathrm{Q}_{10}$ effect. Stable $\mathrm{Po}_{2}$ readings during extended incubations at selected temperatures confirmed that this was accounted for by the slower rate of temperature change in the range between 12 and $0^{\circ} \mathrm{C}$.

Measurements of $\mathrm{Po}_{2}$ as well as heart and ventilation rates allowed determination of threshold temper-
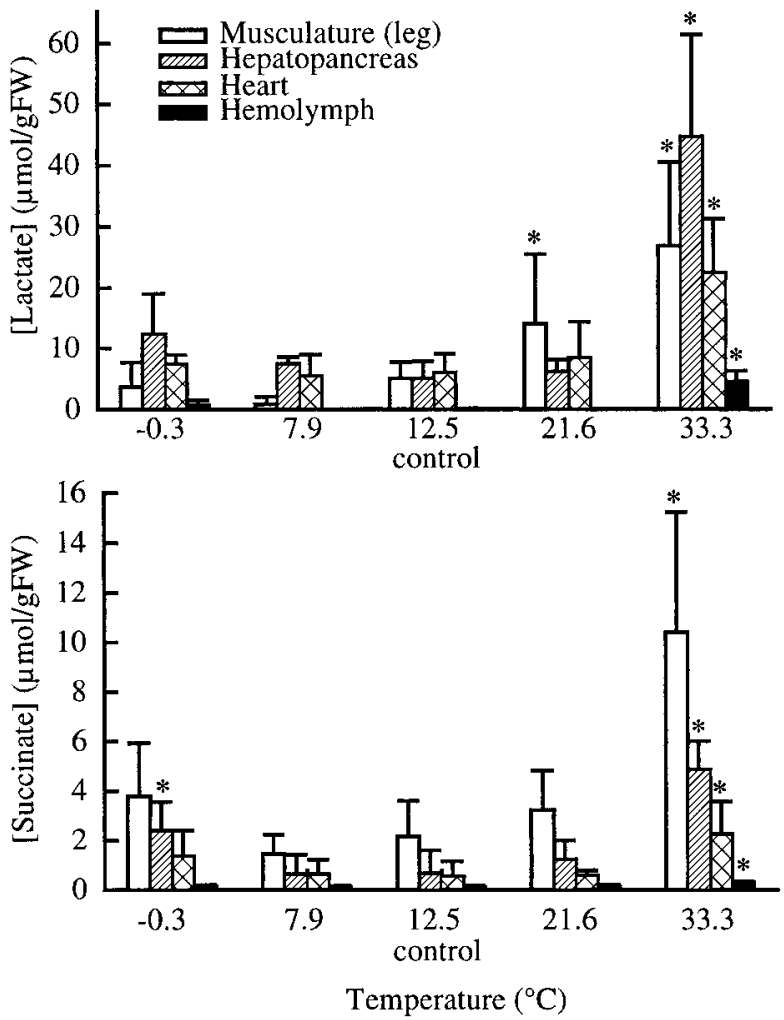

Fig. 4. Concentrations of L-lactate and succinate in musculature, hepatopancreas, heart, and hemolymph after exposure to 5 different temperatures. FW, fresh weight. *Significant difference from control values at $12.5^{\circ} \mathrm{C}$ (ANOVA, $P<0.05$ ). Values are means $\pm \mathrm{SD} ; n=6$. 
atures at the organismic level in the context of changes in lactate and succinate concentrations. Previously, critical temperatures $\left(\mathrm{T}_{\mathrm{c} \text { I }}\right.$ and $\left.\mathrm{T}_{\mathrm{c} \mathrm{II}}\right)$ have been identified by the onset of succinate (and/or acetate) formation, indicating tissue hypoxia, the transition to an anaerobic mitochondrial metabolism, and an elimination of aerobic scope for activity at both critical temperatures (for review, see Refs. 35, 36). The present data confirm that critical temperatures exist in Maja squinado, because the accumulation of lactate and succinate coincided with very low arterial $\mathrm{Po}_{2}$ values and indicates the onset of anaerobiosis at extreme temperatures (Fig. 4). However, major changes in circulatory performance and hemolymph $\mathrm{PO}_{2}$ occurred before critical temperatures were reached (Fig. 2). Threshold temperatures $\left(\mathrm{T}_{\mathrm{p} \mathrm{I}}\right.$ and $\left.\mathrm{T}_{\mathrm{p} \mathrm{II}}\right)$ became visible, which indicated the transition from a temperature range with maximum arterial $\mathrm{Po}_{2}$ to low or high ranges of temperature characterized by falling $\mathrm{Po}_{2}$ values. The progressive drop in arterial $\mathrm{Po}_{2}$ reflects a reduction of $\mathrm{O}_{2}$ availability to mitochondria. This is equivalent to an apparent reduction of mitochondrial aerobic capacity and thereby a reduced scope for aerobic activity of the whole animal despite maintenance of standard metabolism. The concept of "aerobic scope for activity" as defined on the basis of measurements of $\mathrm{O}_{2}$ consumption in fish (4) reflects the range between minimum and maximum $\mathrm{O}_{2}$ consumption by mitochondria and depends on sufficient $\mathrm{O}_{2}$ delivery by ventilation and circulation. Therefore, this concept extends from the whole animal to mitochondrial levels.

The high $\mathrm{PO}_{2}$ between $\mathrm{T}_{\mathrm{p}}$ and $\mathrm{T}_{\mathrm{p} \text { II }}$ was maintained by a progressive increase in ventilation rate with temperature as required to compensate for the rise in $\mathrm{O}_{2}$ demand (Fig. 3). $\mathrm{T}_{\mathrm{p} \text { II }}$ was characterized by a change to more or less constant ventilation rates and onset of a decrease in $\mathrm{Po}_{2}$, reflecting a rising $\mathrm{O}_{2}$ demand in metabolism that was no longer compensated for by ventilation. $\mathrm{T}_{\mathrm{p}}$ was characterized by a sudden decrease in ventilation and heart rates, followed by a decrease in $\mathrm{PO}_{2}$. This threshold is furthermore characterized by a disproportionate reduction in cardiac output and a redistribution of hemolymph from lateral into sternal and hepatic arteries, as shown elsewhere (17). Critical temperatures characterized by the onset of anaerobic metabolism were reached close to 1 or $30^{\circ} \mathrm{C}$, respectively (see Figs. 2 and 4). Lactate accumulated as the main anaerobic end product in crustaceans $(1,19,20$, 43). In addition, an increase in succinate concentrations indicated mitochondrial anaerobiosis (35). Because of the large interval between sampling temperatures and the fast rate of temperature change, a more precise quantification of $\mathrm{T}_{\mathrm{c} I}$ and $\mathrm{T}_{\mathrm{c} \text { II }}$ is not possible. For survival in the natural environment, however, the thresholds $\mathrm{T}_{\mathrm{p} \mathrm{I}}$ and $\mathrm{T}_{\mathrm{p} \mathrm{II}}$ may have greater importance (see below).

The processes causing tissue hypoxia appeared to be similar at low and high temperatures. Between 8 and $0^{\circ} \mathrm{C}$, a reduction in heart rate, ventilation rate, and $\mathrm{Po}_{2}$ occurred with similar slopes $\left(10 \pm 1.7 \% /{ }^{\circ} \mathrm{C}\right)$. Cooling caused whole animal metabolism and all $\mathrm{O}_{2}$-consum- ing and $\mathrm{O}_{2}$-delivering processes (ventilation rate and hemolymph circulation) to slow down. Finally, insufficient performance of ventilation and circulation caused tissue hypoxia and transition to anaerobiosis at the critical temperature before torpor and death. Accumulated amounts of anaerobic end products were small (Fig. 4), reflecting the low metabolic rate and, possibly, a considerable fraction of aerobic metabolism just below $\mathrm{T}_{\mathrm{c} I}$.

Reduced $\mathrm{O}_{2}$ availability also became visible during warming above $17^{\circ} \mathrm{C}$. Heart rate increased but no longer followed the $\mathrm{Q}_{10}$ relationship. Ventilation rate and, therefore, $\mathrm{O}_{2}$ supply no longer continued to rise above $17^{\circ} \mathrm{C}$. Again, limited performance of ventilation and circulation contributed to the decrease in $\mathrm{Po}_{2}$ observed between 17 and $30^{\circ} \mathrm{C}$. Above $30^{\circ} \mathrm{C}$, tissue hypoxia caused lactate and succinate to accumulate in different tissues and heart beat and ventilation started to collapse. The concentrations of lactate found at $33.3^{\circ} \mathrm{C}$ after progressive warming were of the same order of magnitude as reported for different decapod species after 6-12 h of exposure to environmental hypoxia at intermediate temperatures $(20,21,50)$. Survival under these anaerobic conditions will depend on the combination of both the duration of exposure and temperature.

We believe that these findings may have general relevance for understanding thermal tolerance and, possibly, for explaining the geographic distribution of marine invertebrates (see below). The ecological concept of the "law of tolerance" of Shelford $(38,39)$ was defined according to the range of tolerance to abiotic factors like temperature, humidity, or light. The optimum in the middle of the tolerance range is encompassed by both a low and a high pejus range (Ref. 37; pejus = turning worse, becoming deleterious) during transition to upper and lower limits. Within pejus ranges survival is still possible, but performance is

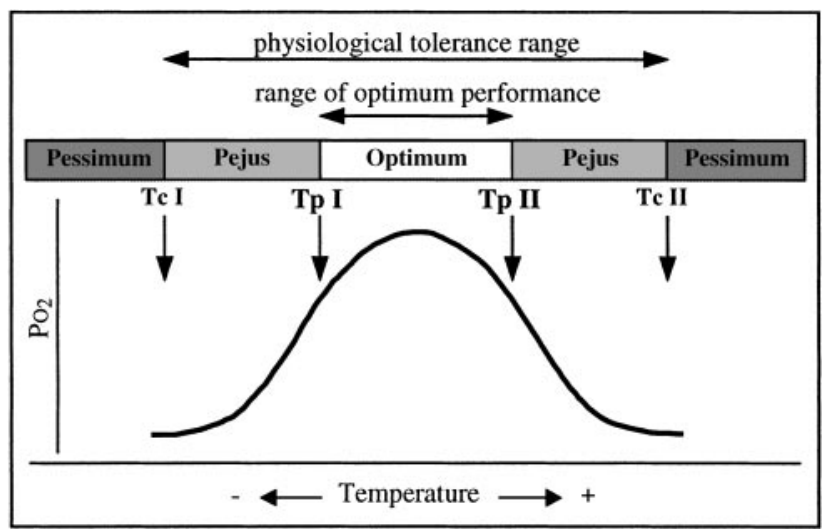

Fig. 5. Model of temperature tolerance adapted from Shelford's law of tolerance. The critical temperatures $\mathrm{T}_{\mathrm{cI}}$ and $\mathrm{T}_{\text {cII }}$ are characterized by the transition to anaerobic metabolism and indicate the physiological tolerance range. The pejus temperatures $\mathrm{T}_{\mathrm{pI}}$ and $\mathrm{T}_{\mathrm{pII}}$ characterize the transition from optimum to pejus range and indicate the optimum performance range. Possibly, the latter is identical with the ecological tolerance range, because actual water temperatures in the environment of the investigated population vary between $\mathrm{T}_{\mathrm{PI}}$ and $\mathrm{T}_{\mathrm{pII}}$ (see Perspectives). 
restricted. Our data suggest that it is possible to use physiological break points within this concept. In Maja squinado, an optimum range was found between 8 and $17^{\circ} \mathrm{C}$ (Fig. 5). This range is characterized by maximum $\mathrm{PO}_{2}$ and represents the temperature window of maximum scope for aerobic activity. It therefore indicates the range of optimum performance supporting successful survival in the natural environment. We suggest that those thresholds limiting the optimum range be called "pejus temperatures," $\mathrm{T}_{\mathrm{p}}\left(8^{\circ} \mathrm{C}\right)$ and $\mathrm{T}_{\mathrm{p} \text { II }}\left(17^{\circ} \mathrm{C}\right)$. Beyond $\mathrm{T}_{\mathrm{pI}}$ and $\mathrm{T}_{\mathrm{p} \text { II }}$, falling $\mathrm{PO}_{2}$ values indicate a reduced scope of aerobic energy production until critical temperatures $\mathrm{T}_{\mathrm{c} \text { I }}$ and $\mathrm{T}_{\mathrm{c} \mathrm{II}}$ are reached, characterized by low $\mathrm{PO}_{2}$ values and the transition to anaerobic metabolism (Fig. 5). Finally, pessimum ranges (pessimum $=$ worst, lethal range) extend beyond critical temperatures and the limits of tolerance. Animals are still able to survive within the physiological tolerance range between $T_{c I}$ and $T_{c I I}$, however, with largely reduced scope for activity toward both extremes (pejus ranges).

As a corollary, limited ventilation and circulation performance leads to an $\mathrm{O}_{2}$ limitation of thermal tolerance at both low and high temperature extremes. The development of hemolymph $\mathrm{Po}_{2}$ with changing temperature characterizes the range of optimum $\mathrm{O}_{2}$ availability as well as these $\mathrm{O}_{2}$ limitations. Pejus temperatures define the transition to low and high ranges of progressively decreased $\mathrm{O}_{2}$ availability (pejus ranges) until critical temperatures finally indicate tissue hypoxia and onset of anaerobic metabolism. Future study must investigate these ranges and thresholds in a wide range of animal species to test the general applicability of concepts and terms used in the present paper.

\section{Perspectives}

Two key questions characterize the perspectives originating from this study.

What is the ecological relevance of an oxygen-limited thermal tolerance and associated threshold (i.e., pejus and critical) temperatures? As a preliminary answer, the pejus temperatures at 8 and $17^{\circ} \mathrm{C}$ agree well with the temperature fluctuations of the English Channel, which is the natural environment of the investigated population. Bottom $(60 \mathrm{~m})$ mean temperatures vary between $9.1^{\circ} \mathrm{C}$ in winter and $16.0^{\circ} \mathrm{C}$ in summer $(10$, 42). It thus appears possible that pejus temperatures, i.e., those temperatures limiting the range of maximum performance and scope for activity, are equivalent to those defining the limits of geographic distribution. However, the animals used in the present study were acclimated to only one (mean) temperature, and the experimental protocol led to the determination of the acute tolerance window. This window may shift between seasons depending on thermal acclimation. This immediately leads to the second question.

Which mechanisms may be responsible for setting pejus and critical temperatures depending on acclimation, season, and latitude? In the lugworm Arenicola marina, it has been demonstrated that both critical temperatures shift in parallel, as shown for two different populations in a latitudinal cline $(40,41)$. Higher mitochondrial densities were found in cold-adapted populations of Arenicola marina (41) and in coldadapted perciform fishes (24). Our current hypothesis is that a downward shift in critical (and possibly pejus) temperatures involves a rise in mitochondrial density and tissue aerobic capacity, whereas an upward shift is linked to a decrease in these parameters $(35,36)$. Mitochondrial proliferation in the cold supports maintenance of sufficient aerobic capacity and function in all tissues, including those responsible for ventilation and circulation. In the warm, however, $\mathrm{O}_{2}$ demand by mitochondria may become limiting, especially at high densities. Proton leakage at the inner mitochondrial membrane is suggested to represent the cost of mitochondrial maintenance, leading to a higher $\mathrm{O}_{2}$ demand with a higher number of mitochondria present and, accordingly, a downward shift of upper critical (and possibly pejus) temperatures in cold-adapted animals $(35,36)$. Data on $\mathrm{O}_{2}$ consumption in fiddler crabs, Uca sp., from different latitudes $(46,47)$ suggest that the process of cold adaptation and an associated rise in metabolic rate take place in decapod crustaceans as well. Accordingly, thermal limits of in vivo heart rates varied between species of porcelain crabs depending on the temperatures experienced at different vertical levels in the intertidal zone (44). However, it remains to be investigated to what extent Maja squinado would be able to shift its range of thermal tolerance in accordance with its wide range of geographic distribution.

The technical support of D. Storch and I. Pinz during tissue sampling and metabolite measurements is gratefully acknowledged.

Present address of M. Frederich: Brigham and Women's Hospital, Harvard Medical School, Boston, MA 02115.

\section{REFERENCES}

1. Albert JL and Ellington WE. Patterns of energy metabolism in the stone crab, Menippe mercenaria, during severe hypoxia and subsequent recovery. J Exp Zool 234: 175-183, 1985.

2. Angersbach $\mathbf{D}$ and Decker $\mathbf{H}$. Oxygen transport in crayfish blood: effect of thermal acclimation and short-term fluctuation related to ventilation and cardiac performance. J Comp Physiol 123: 105-112, 1978.

3. Beis I and Newsholme EA. The contents of adenine nucleotides, phosphagens and some glycolytic intermediates in resting muscles from vertebrates and invertebrates. Biochem $J$ 152: 23-32, 1975.

4. Bennett AF. Activity metabolism of the lower vertebrates. Annu Rev Physiol 400: 447-469, 1978.

5. Bergmeyer HU. Methods of Enzymatic Analysis (3rd ed.). Weinheim, Germany: VCH, vols. 1-12, 1985.

6. Booth CE, McMahon BR, and Pinder AW. Oxygen uptake and the potentiating effects of increased hemolymph lactate on oxygen transport during exercise in the blue crab, Callinectes sapidus. J Comp Physiol 148: 111-121, 1982.

7. Burggren W, McMahon BR, and Powers D. Respiratory functions of blood. In: Environmental and Metabolic Animal Physiology, edited by Prosser CL. New York: Wiley-Liss, 1991, p. 437-508.

8. Cameron JN and Mangum CP. Environmental adaptations of the respiratory system: ventilation, circulation, and oxygen transport. In: The Biology of Crustacea, edited by Vernberg FJ and Vernberg WB. New York: Academic, 1982, vol. 8, p. 43-63.

9. Christiansen ME. Marine Invertebrates of Scandinavia. 2. Decapoda Brachyura. Oslo: Universitetsforlaget, 1969, p 1-143. 
10. Dauvin J-C, Joncourt M, and Birrien J-L. Température et salinité de l'eau de mer au large de Roscoff de 1988 à 1990. Cah Biol Mar 32: 545-550, 1991.

11. Depledge MH. Photoplethysmography—a non-invasive technique for monitoring heart beat and ventilation rate in decapod crustaceans. Comp Biochem Physiol A Physiol 77: 369-371, 1984.

12. DeWachter B and McMahon BR. Temperature effects on heart performance and regional hemolymph flow in the crab Cancer magister. Comp Biochem Physiol A Physiol 1141: 27-33, 1996.

13. DeWachter B and Wilkens JL. Comparison of temperature effects on heart performance of the Dungeness crab, Cancer magister, in vitro and in vivo. Biol Bull 190: 385-395, 1996.

14. Florey $\mathbf{E}$ and Kriebel ME. The effects of temperature, anoxia and sensory stimulation on the heart rate of unrestrained crabs. Comp Biochem Physiol A Physiol 48: 285-300, 1974.

15. Forgue J, Truchot J-P, and Massabuau J-C. Low arterial $\mathrm{PO}_{2}$ in resting crustaceans is independent of blood oxygen-affinity. J Exp Biol 170: 257-264, 1992.

16. Foyle TP, O'Dor RK, and Elner RW. Energetically defining the thermal limits of the snow crab. J Exp Biol 145: 371-393, 1989.

17. Frederich M, DeWacher B, Sartoris FJ, and Pörtner HO. Thermal tolerance and the regulation of cardiac performance and haemolymph distribution in Maja squinado (Crustacea: Decapoda). Physiol Biochem Zool In press.

18. Frederich M, Sartoris FJ, Arntz WE, and Pörtner HO. Haemolymph $\mathrm{Mg}^{2+}$ regulation in decapod crustaceans: physiological correlates and ecological consequences in polar areas. $J$ Exp Biol 203: 1383-1393, 2000.

19. Gäde G. Energy metabolism of arthropods and molluscs during environmental and functional anaerobiosis. J Exp Zool 228: $415-429,1983$

20. Gäde $\mathbf{G}$ and Meinardus-Hager G. Anaerobic energy metabolism in Crustacea, Xiphosura and Mollusca: lactate fermentation versus multiple fermentation products. Zool Beitr NF 30: 187203, 1986.

21. Hill AD, Taylor AC, and Strang RHC. Physiological and metabolic responses of the shore crab Carcinus maenas (L.) during environmental anoxia and subsequent recovery. $J$ Exp Mar Biol Ecol 150: 31-50, 1991.

22. Hines AH, Wolcott TG, González-Gurriarán E, GonzálezEscalante JL, and Freire J. Movement patterns and migrations in crabs: telemetry of juvenile and adult behaviour in Callinectes sapidus and Maja squinado. J Mar Biol Assoc UK 75: 27-42, 1995.

23. Ivleva IV. The dependence of crustacean respiration rate on body mass and habitat temperature. Int Rev Ges Hydrobiol 65: $1-47,1980$.

24. Johnston IA, Calvo J, Guderley H, and Palmer FL. Latitudinal variation in the abundance and oxidative capacities of muscle mitochondria in perciform fishes. J Exp Biol 201: 1-12, 1997.

25. Klimant I, Meyer V and Kühl M. Fiber-optic oxygen microsensors, a new tool in aquatic biology. Limnol Oceanogr 40: 1159$1165,1995$.

26. Klimant I, Kühl M, Glud RN, and Holst G. Optical measurement of oxygen and temperature in microscale: strategies and biological applications. Sensors Actuators B Chemical 38: 29-37, 1997.

27. Mangum CP. Respiratory function of the haemocyanins. Am Zool 29: 19-38, 1980.

28. Mangum CP. Oxygen transport in the blood. In: The Biology of Crustacea, edited by Mantel LH. New York: Academic, 1983, vol. 5 , p 373-429.

29. Mauro NA and Mangum CP. The role of the blood in the temperature dependence of oxidative metabolism in decapod crustaceans. I. Intraspecific responses to seasonal differences in temperature. J Exp Zool 219: 179-188, 1982.

30. Massabuau J-C and Forgue J. A field versus laboratory study of blood oxygen status in normoxic crabs at different temperatures. Can J Zool 74: 423-430, 1996.
31. McDonald DG, McMahon BR, and Wood CM. Patterns of heart and scaphognathite activity in the crab Cancer magister. $J$ Exp Zool 202: 33-44, 1977.

32. McMahon BR and Wilkens JL. Periodic respiratory and circulatory performance in the red rock crab Cancer productus. $J$ Exp Zool 202: 363-374, 1977.

33. McMahon BR and Wilkens JL. Ventilation, perfusion and oxygen uptake. In: The Biology of Crustacea, edited by Mantel LH. New York: Academic, 1983, vol. 5, p 289-372.

34. Nakamura M, Tani M, and Kuramoto T. Effects of rapid cooling on heart rate of the Japanese lobster in vivo. Zool Sci 11: $375-379,1994$

35. Pörtner HO, Hardewig I, Sartoris FJ, and van Dijk PLM. Energetic aspects of cold adaptation: critical temperatures in metabolic, ionic and acid-base regulation? In: Cold Ocean Physiology, edited by Pörtner HO and Playle R. Cambridge, UK: Cambridge Univ. Press, 1998, p. 88-120.

36. Pörtner HO, van Dijk PLM, Hardewig I, and Sommer A. Levels of metabolic cold adaptation: tradeoffs in eurythermal and stenothermal ectotherms. In: Antarctic Ecosystems: Models for Wider Ecological Understanding, edited by Davison W and Williams CH. Christchurch, New Zealand: Caxton. In press.

37. Schwerdtfeger F. Ökologie der Tiere: Autökologie. Hamburg, Germany: Verlag Paul Parey, 1977, p. 1-460.

38. Shelford VE. Animal Communities in Temperate America. Chicago, IL: Univ. of Chicago Press, 1913, p. 1-368.

39. Shelford VE. Some concepts of bioecology. Ecology 123: 455467, 1931.

40. Sommer A, Klein B, and Pörtner HO. Temperature induced anaerobiosis in two populations of the polychaete worm Arenicola marina (L.). J Comp Physiol [B] 167: 25-35, 1997.

41. Sommer A and Pörtner HO. Exposure of Arenicola marina (L.) to extreme temperatures: adaptive flexibility of a boreal and a subpolar population. Mar Ecol Prog Ser 181: 215-226, 1999.

42. Sournia A and Birrien J-L. La série océanographique côtière de Roscoff (Manche occidentale) de 1985 à 1992. Cah Biol Mar 36: 1-8, 1995.

43. Spicer JI, Hill AD, Taylor AC, and Strang RHC. Effect of aerial exposure on concentrations of selected metabolites in blood of the Norwegian lobster Nephrops norvegicus (Crustacea: Nephropidae). Mar Biol (Berl) 105: 129-135, 1990.

44. Stillman JH and Somero GN. Adaptation to temperature stress and aerial exposure in congeneric species of intertidal porcelain crabs (genus Petrolisthes): correlation of physiology, biochemistry and morphology with vertical distribution. $J$ Exp Biol 199: 1845-1855, 1996.

45. Truchot J-P. Etude comparée de la fixation de l'oxygén par la sérum de cinq espèces de Crustacés Décapodes Brachyoures. $C R$ Seances Acad Sci D: 2706-2709, 1971.

46. Vernberg FJ and Vernberg WB. Metabolic adaptation of animals from different latitudes. Helgo Wiss Meers 9: 476-487, 1964.

47. Vernberg FJ and Costlow JD Jr. Studies on the physiological variation between tropical and temperate zone fiddler crabs of the genus Uca. IV. Oxygen consumption of larvae and young crabs reared in the laboratory. Physiol Zool 39: 36-52, 1966

48. Wollenberger A, Ristau O, and Schoffa G. Eine einfache Technik der extrem schnellen Abkühlung größerer Gewebestücke. Pflügers Arch 270: 399-412, 1960.

49. Yeager DP and Ultsch GR. Physiological regulation and conformation: a BASIC program for the determination of critical points. Physiol Zool 62: 888-907, 1989.

50. Zebe E. Anaerobic metabolism in Upogebia pugettensis and Callianassa californiensis (Crustacea, Thalassinidea). Comp Biochem Physiol B Biochem Mol Biol 724: 613-617, 1982.

51. Zielinski S, and Pörtner HO. Energy metabolism and ATP free-energy change of the intertidal worm, Sipunculus nudus, below a critical temperature. J Comp Physiol [B] 166: 492-500, 1996. 